\title{
Intersectional Individuality: Georg Simmel's Concept of "The Intersection of Social Circles" and the Emancipation of Women
}

Stoetzler, Marcel

\section{Sociological Inquiry}

DOI:

$10.1111 /$ soin. 12110

Published: 18/04/2016

Peer reviewed version

Cyswllt i'r cyhoeddiad / Link to publication

Dyfyniad o'r fersiwn a gyhoeddwyd / Citation for published version (APA):

Stoetzler, M. (2016). Intersectional Individuality: Georg Simmel's Concept of "The Intersection of Social Circles" and the Emancipation of Women. Sociological Inquiry, 86(2), 216-240. https://doi.org/10.1111/soin.12110

\section{Hawliau Cyffredinol / General rights}

Copyright and moral rights for the publications made accessible in the public portal are retained by the authors and/or other copyright owners and it is a condition of accessing publications that users recognise and abide by the legal requirements associated with these rights.

- Users may download and print one copy of any publication from the public portal for the purpose of private study or research.

- You may not further distribute the material or use it for any profit-making activity or commercial gain

- You may freely distribute the URL identifying the publication in the public portal ?

Take down policy

If you believe that this document breaches copyright please contact us providing details, and we will remove access to the work immediately and investigate your claim. 
Intersectional individuality: Georg Simmel's concept of 'the intersection of social circles' and the emancipation of women

Marcel Stoetzler, Bangor University

Abstract: Georg Simmel's 'The intersection of social circles', a chapter in his 1908 Sociology, contains discussions of class, religion, ethnic and gender relations that are highly relevant to contemporary sociological concerns. Simmel's argument is based on a notion of historical dynamic that interprets increasingly complex intersectionality as a sign of progressing civilization. The article establishes how Simmel describes 'the intersection of social circles' and then looks at Simmel's account through the concept of 'intersectionality' as developed in contemporary feminist theory. The article suggests that although some aspects of Simmel's account of women in modernity are incompatible with contemporary feminism, the shared use of the same image, 'intersection', in Simmel and in contemporary feminist theory is the symptom of a shared concern with a particular aspect of the complexity of modern society. In Simmel, the increasing density of the intersections of social circles points to the increasingly complex individuality of modern subjects, whereas the use of the same image in contemporary feminist theory is part of a critique of inequality and oppression in the same modern society whose advent Simmel celebrated. Intersectionality is a characteristic of modern society that first became visible more than a century ago and has meanwhile become ever the more a signature of modernity.

'The intersection of social circles' ('Die Kreuzung sozialer Kreise') is the title of the sixth chapter of Georg Simmel's book Sociology of 1908 (Simmel 1992). This chapter incorporates a (much shorter) chapter from Simmel's first sociological study, On Social Differentiation (Über sociale Differenzierung) from 1890 (Simmel 1989). I will in the body of this article examine the 1908 version of this text with a focus on how it discusses issues of race, class, gender and religion, suggesting that Simmel anticipated some aspects of contemporary discussions of these issues, while differing in others. Amongst contemporary social theory, I am here particularly interested in the comparison with discussions in feminist and anti-racist theory of 'intersectionality' as the shared use of the image of the 'intersection' points to 
shared theoretical concerns with modern society that bridge the temporal divide between the late nineteenth and the late twentieth centuries respectively. The article makes in this manner a plea for the fruitfulness of dialogues between classical and contemporary social theory.

Simmel adopted the concept of the 'intersection of social circles' from his teacher Moritz Lazarus who introduced the image in a text first published in $1862:^{1}$

Within the large circle of society, smaller circles form, and ever narrower ones all the way down to the family. These circles do not stand one next to the other, but they intersect (durchschneiden) and touch in many ways. In this way a multiply intertwined relationship of connection and separation emerges within society. Accordingly the individual participates in the universal spirit (Gesammtgeiste) in multiply differing directions and intensities, allowing the emergence of an immense multiplicity of personal individualities (Lazarus 2003, pp. 50-1).

Lazarus' concern is here with the relationship of individual and society, and whatever groups and relationships - 'circles' - stand in between, a concern in which he was followed by Simmel. Lazarus chiefly asks how, and how intensively, the individual partakes in the 'universal spirit' of the (national) society of which this individual is a member. ${ }^{2}$ Lazarus' term 'universal spirit' ('Gesammtgeist') corresponds here roughly to what cultural anthropology and sociology later would refer to as 'a culture'. ${ }^{3}$ Lazarus was a leading figure in the Jewish community of Berlin and became in the 1880s a key spokesman in the fight against the emergent movement of political antisemitism. One of his crucial contributions in this context was a lecture given in Berlin in 1879 (while Simmel was a student there) titled 'What does National mean?' (Lazarus 2008) that is in many respects an articulation of multicultural liberalism avant la lettre (Stoetzler $2008 a$ and $b$, 2014): Lazarus is in this respect also a founding figure of anti-racist social science.

\footnotetext{
${ }^{1}$ Lazarus was also a German nationalist and early advocate of Prussian hegemony within Germany (Belke 1971).

${ }^{2}$ The relationship of individual and collectivity in Lazarus and Simmel is discussed in Schmid (2005). Frisby (1992, p. 8) points to Lazarus' authorship of the concept of the intersection of social circles.

${ }^{3}$ The reference to the 'universal spirit', the 'Gesammtgeist' is central to the project of Völkerpsychologie that Lazarus inaugurated, the 'science of folk spirits' that was the precursor of cultural anthropology. The latter's pioneer Franz Boas, was like Simmel strongly influenced by Lazarus (Kalmar 1987; Bunzl 2003).
} 
Lazarus and Simmel discuss and welcome increased individuality and diversity through multiplied intersectionality as a characteristic of modernity. This general notion, if not the word, can surely be seen as one of several ideas that undergirded what was then emerging as the new discipline of sociology. Rather intriguingly, the exact same notion is also expressed in one of the foundational texts of American sociology, Charles H. Cooley's Human Nature and the Social Order of 1902. As in Simmel, the context is the discussion of the specific character of social life in modernity:

Again, the life of this age is more diversified than life ever was before, and this appears in the mind of the person who shares it as a greater variety of interests and affiliations. A man may be regarded as the point of intersection of an indefinite number of circles representing social groups, having as many arcs passing through him as there are groups. This diversity is connected with the growth of communication, and is another phase of the general enlargement and variegation of life. Because of the greater variety of imaginative contacts it is impossible for a normally open-minded individual not to lead a broader life, in some respects at least, than he would have led in the past (Cooley 1922 [1902], pp. 147-8). ${ }^{4}$

Neither Lazarus nor Cooley, though, made as systematic use of the image as Simmel did. The fact that not many readers of Simmel will be aware of this has a simple reason: Simmel's concept of the 'intersection of social circles' was - more or less, and for a long time - lost in translation. The standard volume edited by Kurt H. Wolff in 1950, The Sociology of Georg Simmel, does not contain the chapter 'Die Kreuzung sozialer Kreise', a fact that is mentioned in the introduction where the missing chapter is referred to accurately as 'The intersection of social circles' (Simmel 1950, p. 1xii). The chapter was subsequently published in English in 1955 in the volume Conflict/ The Web of Group-Affiliations, also edited by Wolff. Crucially, though, the translator Reinhard Bendix rendered the title of the chapter in this edition as 'The Web of Group-Affiliations', and it is under this title that the text has become a sociological

\footnotetext{
${ }^{4}$ This is from chapter 4. I am not aware of any references to Simmel in Cooley, although he could have known Simmel's work of 1890. Jacobs (2006, p. 66) remarks that the quoted passage is 'reminiscent of Simmel'. Cooley mentioned Simmel in a journal (Jacobs 2006, p. 12). Also Rieff (1993, p. xxiv) points to a similarity between Cooley and Simmel. One point of reference shared by Cooley and Simmel is their enthusiasm for Goethe (Coser 2003, pp. 319 and 198).
} 
key text, most notably perhaps in 'network theory' where 'network' represents what Bendix rendered as 'web'. Bendix made his choice of wording explicit in a translator's footnote, stating that "literal translation of this phrase, "intersection of social circles", is almost meaningless' (Simmel 1955, p. 125). Although Bendix felt that replacing the metaphor of the 'intersection' with that of the 'web' constituted an improvement on Simmel's own choice of words, it meant reducing the complexity of Simmel's deliberately ambiguous, namely concrete as well as abstract, term 'circles' to the unequivocal concreteness of the term 'groups ${ }^{6}{ }^{6}$ For these reasons, 'the intersection of social circles' went incognito in 1955; under the false flag of 'webs' and 'networks' it then engaged on a splendid career. 'Although Bendix's translation of 1955 still contains occurrences of the word 'intersect' (e.g. on pages 150 and 153), and in spite of its parallel occurrence in Cooley, the image of 'the intersection' played no important part in sociological theorizing until it was reinvented at the end of the 1980s in the context of the feminist-antiracist discourse on 'intersectionality'.

'Intersectionality', which is now one of the most prominent concepts used in feministinspired critical theorizing of social divisions and inequality including amongst others those of race, class, gender, age, sexuality and disability, denotes the fact that 'intersecting' social divisions (or categories, or 'belongings') mutually construct each other's specific and complex, often contradictory societal meanings and functions. The intersectionality approach aims to replace an additive, more mechanical manner of imagining the intersections of social circles - individual $\mathrm{X}$ is ' $\mathrm{a}$ ' but at the same time also ' $\mathrm{b}$ ' - by a more dynamic mode holding that individual $\mathrm{X}$ is ' $\mathrm{a}$ ' in a ' $b$ ' kind of manner and ' $\mathrm{b}$ ' in an ' $a$ ' kind of manner. Elizabeth Spelman, whose book Inessential Woman of 1988 was a crucial contribution to the formation of the feminist intersectionality discourse, argues that paying attention to the mutual

\footnotetext{
${ }^{5}$ On Simmel in 'network theory', see Levine et al. 1976; Breiger 1974; Pescosolido and Rubin 2000; Diani 2000; Nollert 2010; Erikson 2011. Rock (1979) discusses Simmel's influence on the 'Chicago school'. Schober (2009) examines parallels between Simmel's concept of 'intersections' and some aspects of mostly post-Gramscian, British Cultural Studies discourses. Petzke (2011) discusses Simmel's chapter on 'the intersection of social circles' in relation to Dilthey, another philosopher strongly influenced by Moritz Lazarus, and Max Weber.

${ }^{6}$ In the new translation of 2009, the chapter is included and titled accurately 'The intersection of social circles' (Simmel 2009). In Bendix's defence it must be said that Simmel used the words 'circle' and 'group' often in a way that made them seem interchangeable. Nevertheless it is crucial to keep in mind that 'Kreise' (circles) means in Simmel's use abstract 'category' as well as concrete 'group'.

${ }^{7}$ Coser points to the liberal connotations of Simmel's concept of the 'intersections of social circles' (Coser 2003, pp. 190-1).
} 
constitution of the intersecting categories in the moment of their intersection is important not only for identifying and empowering 'the most oppressed' but just as importantly for understanding any subject position in society:

The oppression white middle-class women are subject to is not the oppression women face 'as women' but the oppression white middle-class women face. Their race and class are not irrelevant to the oppression they face even though they are not oppressed on account of their race and class (Spelman 1988, p. 77).

Spelman argues that 'additive analyses of identity and oppression can work against an understanding of the relations between gender and other elements of identity, between sexism and other forms of oppression' (Spelman 1988, p. 115); for example, to say simply that Black women experience 'sexism and racism' suggests 'that Black women experience one form of oppression, as Blacks (the same thing Black men experience) and that they experience another form of oppression, as women (the same thing white women experience)' (Spelman 1988, p. 122). This is not the case, though:

How one form of oppression is experienced is influenced by and influences how another form is experienced. An additive analysis treats the oppression of a Black woman in a society that is racist as well as sexist as if it were a further burden when, in fact, it is a different burden ... sexism and racism must be seen as interlocking, and not as piled upon each other (Spelman 1988, p. 123).

Central to the feminist discourse on intersectionality is a critique of the more traditional notion of the 'triple oppression' of e.g. Black working class women, considering the latter 'unsatisfactory because it treats forms of subordination and oppression through race, sex, and class as cumulative' when the point is rather to understand them 'as articulating or intersecting together to produce specific effects' which 'cannot be mechanistically understood. It is the intersection of subordinations that is important and they cannot be treated as different layers of oppression' (Anthias and Yuval-Davis 1993, p. 100). The feminist discourse on intersectionality will be discussed further down. ${ }^{8}$

\footnotetext{
${ }^{8}$ The only reference to Simmel in the 'intersectionality' discourse I know of is in a text by Walby in which she proposes adding 'complexity theory' to 'dual systems theory'. Walby
} 
Before turning to a discussion of Simmel's conception of intersectional individuality through the lenses of the contemporary intersectionality discourse in the latter part of the article, I will in the first step now retrace how Simmel develops his concept of the 'intersection of social circles' and then in a second step focus on how he deploys it in the context of women's emancipation. In his characteristic manner, Simmel proceeds by going through an extended series of examples, layering different aspects of the concept onto each other, a method of presentation that is similar to what Walter Benjamin and Theodor W. Adorno (under Simmel's influence) later would refer to as a 'constellation' or 'configuration' of concepts (Benzer 2011, p. 162). No less typical of Simmel's discourse is that he includes gender, nationality and race issues in his conceptual argument.

\section{INTERSECTIONAL PERSONALITY IN 'THE INTERSECTION OF SOCIAL CIRCLES’}

Simmel introduces the problem early in the chapter with a short paragraph on the observation that Australian aborigines are members of totemic associations as well as of tribes, which constitutes the most elementary, or 'primitive' form of an intersection of social circles. Simmel suggests that the complexity achieved by this primitive form of intersectionality enriches the aborigines' social life. From here Simmel jumps straight to 'modern family life' (Simmel 1992, p. 461; 1955, p. 133; 2009, p. 367), arguing that 'the solidarity among members of the same sex' produces a similar form of complexity within modern families:

For example, a mother's instincts will cause her to side with her son as her own kin on occasions when she is drawn into the disputes between him and his wife. But on another occasion her instincts may cause her to take the side of her daughter-in-law as a member of her own sex (als Geschlechtsgenossin) $(461 ; 133 ; 367){ }^{9}$

Simmel adds that this applies 'only insofar as her instincts are acted out a priori, and without regard to all the individual nuances of the case.' Simmel states:

references 'The Web of Group-Affiliations' stating that social systems are 'porous and weblike' (Walby 2007, p. 460).

${ }^{9}$ In the following references the first numbers are to the German text (Simmel 1992), the second number to the translation by Bendix (Simmel 1955), and the third number to the new translation (Simmel 2009). All translations from Simmel's 'The intersection of social circles' are based on Simmel 1955, amended with the help of Simmel 1992 and Simmel 2009. 
To belong to the same sex (Geschlechtsgleichheit) is one of the causes of collective action (Einigungsursachen), which pervade social life perennially, and which intermingles with all other causes of collective action in the most varied ways and degrees $(461 ; 133 ; 367)$.

In the next step of his argument Simmel states that belonging to an age group (Altersgleichheit) is similar to belonging to a sex group (Geschlechtsgleichheit) as a 'basis of division' (Einteilungsgrund). Significantly, though, Simmel frames his argument within a historical perspective and a concern with the concepts of modernity and individuality that underlies his sociology as a whole: he suggests that 'age-groups provide such a basis of solidarity only when the culture is still without an extensive intellectual life' $(462 ; 134 ; 368)$ because the latter fosters 'the unfolding of individual intellectual differences' resulting in ideologies and parties. 'Extensive intellectual life' produces more circles, more intersections and thus reduces the relevance of the more 'organic' (this seems to mean, primitive) modes of belonging such as age and sex. Simmel contrasts the family as one of the simplest with the 'republic of scholars' (Gelehrtenrepublik) as one of the most complex and diverse 'social circles' $(462 ; 135 ; 368)$. Simmel argues that historically, circles of more recent origin tend to be more rational and give the 'appearance of being determined by a purpose, since their affairs revolve around intellectually articulated interests' $(463 ; 137 ; 370)$. Apart from the increasingly intellectual and rational character of newly emerging, more modern circles, Simmel argues their multiplication is itself a hallmark of historical evolution, and, by implication, of civilizational progress: 'The number of different social circles in which the individual is positioned is one of the benchmarks of civilization (Gradmesser der Kultur)' $(464 ; 138 ; 370)$. Simmel refers to the Middle Ages as a foil against which to contrast the modernity of multiply intersecting circles: some typically medieval circles such as guilds explicitly banned their members from belonging to a series of other circles: belonging to a particular guild meant by definition that one did not belong to the circles, or categories, 'woman' or 'Jew', for example. More modern circles are less exclusive and make thereby the positioning of individuals increasingly complex.

The concept of intersecting circles is crucial to Simmel's concept of personality: 
The groups to which the individual belongs constitute a system of coordinates, as it were, such that each additional group to which he belongs determines him more exactly and more unambiguously ... the larger the number of circles to which an individual belongs, the more improbable is it that other persons will exhibit the same combination of group-affiliations, that these particular circles will intersect once again [in another individual] $(466 ; 140 ; 371-2)$.

Simmel adds an interesting aspect of his concept of 'circles' when he states that 'to speak platonically, each thing has a part in as many ideas as it has manifold attributes, and it achieves thereby its individual determinateness (Bestimmtheit)' $(467 ; 140 ; 372)$. This statement in particular illustrates the deliberate ambiguity of Simmel's concept between 'group' (such as a guild) and 'category' (such as sex) which he likens to platonic 'ideas' or essences. The continuous play on this ambiguity and openness is important to Simmel's argument.

Simmel emphasises repeatedly that he aims to describe a historical process, and he characterises this process as bringing benefits as well as problems:

As the individual leaves his established position within one primary group, he comes to stand at a point at which many groups intersect. The individual as a moral personality comes to be circumscribed in an entirely new way, but he also faces new problems. The security and lack of ambiguity in his former position in the first instance gives way to ambivalence in the directions his life takes (Schwankung der Lebenstendenzen). This is the sense of an old English proverb that says: he who speaks two languages is a knave $(467-8 ; 141 ; 372-3)$.

The multiplication of intersecting circles creates problems, but these same problems also have positive effects (again a typical pattern of Simmel's take on modernity): as a kind of counter-tendency, they strengthen what we would now call personal identity (die Einheit der Persönlichkeit, literally: the unity or integration of the personality): 'The ego can become more clearly conscious of this unity, the more he is confronted with the task of reconciling within himself a diversity of group-interests' $(468 ; 142 ; 373)$. 
In Simmel's imagery, belonging to several different circles has differing effects depending on whether these circles are parallel or concentric $(472 ; 147 ; 376)$, a formulation that anticipates the concept of 'nestedness' in complexity theory and the distinction between embedded and dis-embedded ties in network theory. ${ }^{10}$ The modern situation is characterized by an increasing number of non-concentric circles, and therewith intersections, as only nonconcentric circles intersect: 'Standing in the intersection of two circles will define the person the more determinately, the less participation in one circle by itself indicates participation in the other' (p. 474; 150; 378).

Next, Simmel describes cases in which an individual is differently positioned in terms of power or rank in relation to different circles $(478 ; 154 ; 381)$. For example in countries with universal draft an 'intellectually and socially high placed man must obey a noncommissioned officer' $(478 ; 154 ; 381)$. Likewise, 'the tutor of a prince is to be superior to his charge, he is to dominate and direct him - and yet he is, on the other hand, a servant, while his charge is the master. ${ }^{11}$ Other examples Simmel uses are that of business people who are 'in solidarity with each other' in a multiplicity of regards, but competitors in others - again, a significant characteristic of modernity - and that of the member of a political party who cultivates literary, aesthetic or religious tendencies that are typically pursued by members of the opposite party: the individual might deliberately seek such, as it were, inconsistent, affiliations with the intention not to 'surrender' completely to the 'spell of the party' (480; $155-6 ; 382-3)$.

\section{MODERN RELIGION INTERSECTS MANY SOCIAL CIRCLES}

Simmel dedicates a long section to the question of religion. He states that 'religious affiliation is the most important and at the same time the most characteristic example [of the process of individualization] ever since religion has been emancipated from racial, national, or local ties (Lösung der Religion von der stammesmäßigen, nationalen oder lokalen

\footnotetext{
${ }^{10}$ These more contemporary approaches in social theory have replaced more strictly formalized theoretical language for classical social theory's grounding in the philosophy of history. Aiming to rid social theory of the lacunae of nineteenth-century historism, postclassical theory arguably overshot its target by ridding theory of its grounding in history tout court. I see my present attempt as part of a tendency to restore to theory its sense of history. ${ }^{11}$ The teaching situation in the contemporary university is similar: lecturers teach students who are customers in a context where the customer is not just prince but king.
} 
Bindung), a world-historical fact of immeasurable significance' $(480 ; 157 ; 383) .{ }^{12}$ The 'essence' of religion expresses itself equally completely whether the religious community is congruent with the (civic) community in other 'essential or comprehensive interests' or whether it is completely disconnected from such other interests. Simmel states - perhaps, given the historical context of the emerging movement of political antisemitism (Stoetzler 2010), somewhat surprisingly - that 'it is perfectly understandable that the co-existence and the sharing of human interests is not possible with people who do not share one's faith' (480$1 ; 157 ; 383)$. The 'perfectly understandable' need for religious unity was initially satisfied by the fact that religious and societal community coincided, but since this tends not to be the case anymore (chiefly, since the emergence of Christianity), the power of religion shows itself where it unites coreligionists across various differences in other respects $(481 ; 157$; 383). The circle 'religion' intersects in modernity with more or less all other social circles. Simmel discusses in this context several cases: he writes that the 1707 union of England and Scotland was premised on the separation of religious and political constitutions that allowed separate churches to continue to exist that otherwise would have prevented political union $(483 ; 160 ; 385)$. The circles 'nation' and 'religion' had been more or less concentric in the preceding period but now, beginning with the eighteenth century, became less and less concentric (and therewith more intersecting). Simmel reports that in 1896 Jewish workers in Manchester formed an organisation that included Jewish workers of all trades with the intention to cooperate through this organization with (non-Jewish, general) trade unions. They failed to do so, though, because the trade unions insisted on the formation of tradespecific organizations only; the Jewish workers were not numerous enough, however, to form a series of Jewish trade-specific organizations. By contrast, Catholic workers in Germany, being much more numerous, were able to develop Catholic trade unions organized according to trades $(484 ; 161 ; 386)$ : a trade union of Catholic carpenters, for example, itself the intersection of the circles 'Catholics' and 'carpenters', would internally have been concentric and non-intersecting. These are amongst the cases Simmel uses to illustrate his point that the

\footnotetext{
${ }^{12}$ The word 'Stamm' is difficult to translate. Literally denoting the trunk of a tree it can in late nineteenth-century contexts denote a category either below or above the level of the nation, i.e. 'tribe' or 'race'. In liberal-nationalist discourse, the 'stammesmäßigen' divisions within the still not fully established nation were then often understood as representing portions of those larger, world-historical units, the 'races'. Here the sequence 'stammesmäßigen, nationalen oder lokalen Bindung', with the nation in the middle, suggests the meaning 'racial'.
} 
circle 'religion' intersects in various ways with a multiplicity of modern political and social 'circles'.

\section{SIMMEL'S INTERSECTIONAL ACCOUNT OF WORKERS AND WOMEN}

Once religion became non-identical to societal community in general, it came to constitute a 'new' social circle. Simmel discusses the specifically modern circle 'worker' in a similar manner. He uses the opportunity of this particular example to emphasise the role the formation of concepts plays in the process of creating new social circles $(493 ; 172 ; 393)$. 'The identical relation to capital (das gleichmäßige Verhältnis zum Kapital)' unites all wage labourers irrespective of whether they make 'cannons or toys'. This 'identical relation' did not emerge spontaneously, though, but needed to be discovered, understood and articulated, and then acted upon, in order to become actual:

The solidarity of wage labor exemplifies a group-formation based on a pervasive social awareness.... After the various trades have developed out of the growing division of labor, more abstract considerations now cut across the differences between the trades and establish a new social circle $(493 ; 172-3 ; 393-4)$.

Simmel describes this as a process of abstraction: the concept of the wage labourer provides a focus, or 'logical-formal cohesion (logisch-formale Zusammenfassung)' to a set of 'social forces, relations and conditions' $(494 ; 173-4 ; 394)$ to which it then reacts. 'Here, logical and socio-historical processes act and react on one another' $(494 ; 173 ; 394)$. Only 'traversing all differences of trade' made possible the general strike. Simmel emphasises that 'English reactionaries' understood this connection already at the beginning of the nineteenth century when the Corresponding Societies Act banned 'written communication amongst workers' associations' as well as any associations composed by workers of different trades. The 'English reactionaries' feared quite rightly that such communication could create 'a new social circle' and a communality that would neutralise the differences.

Following the description of the constitution of concept and reality of 'wage labourer' through a process of abstraction that allows the 'traversing of differences', Simmel discusses as 'another example for ... a quasi-abstract group' that of women (499; 179; 398). He argues that before the contemporary period, every single woman had been 'confined to a single 
group', the household, not benefiting from any intersections. Due to recent societal developments, women now 'constitute a new social group'. 'Up to now', by contrast and paradoxically, woman had been prevented from 'group-formation (Genossenschaftsbildung) in its strict sense, namely the practical solidarity with the other women' by the most general characteristic of what it meant to be a woman, which had

banned her into the limits of the home, confined [her] to devote herself to particular individuals, and prevented [her] from transcending the group-relations established by marriage, family, social life, and perhaps charity and religion $(499 ; 180 ; 398)$.

'That isolation of women from one another, caused by the integration (Hineinbauung) of each into an entirely individual sphere of interests, was based upon woman's being totally different (völligen Differenz) from man' $(500 ; 181 ; 399)$ : the woman did only what the man did not want or was not able to do. Women were, in other words, prevented from forming a circle of their own (in the double sense of category and group) by being totally different from men: by implication, forming social circles and enjoying the liberating, individualizing effects of their intersections used to be, until very recently, a male privilege. ${ }^{13}$ Simmel's argument assumes here the form of a paradoxical dialectic (Wechselwirkung, reciprocity) that is characteristic of the most inspired moments of his theorizing:

In recent years, women have placed themselves in direct opposition to men in aiming at equalization (Ausgleichung) in all these respects, ... and in occasional beginnings they have succeeded; a partisan assertion of difference (parteimäßige Differenz) from the men, emphasising solidarity of interests amongst women, is emerging - be it as its cause or its effect - just in the same moment that the basic difference from men in terms of being and acting, in legal terms and in terms of interests is diminishing (500; $181 ; 399)$.

Simmel captures here in his theorization of the constitution of 'new' social circles in modernity a peculiar dialectic between identity and difference: the growing self-assertion of

\footnotetext{
${ }^{13}$ As an aside, Simmel notes that 'in primitive ethnological conditions' women's 'dissociation' is less strong: the modern condition that allows the social circle of 'woman' to emerge in a more concrete sense seems almost like a return to a 'primitive' condition.
} 
the new social category 'woman' owes itself to women's becoming less totally different from men, to the extent that they are able now to constitute a 'social circle'. At a (pre-modern) point when women actually were totally different - basically not much more than domestic slaves - they were not able to assert their specific difference and form a circle (category or group). The constitution of an actual category or 'social circle' of women means the 'formation of a higher circle that is defined by a general concept (Bildung eines höheren, durch einen Allgemeinbegriff zusammengeschlossenen Kreises)' (501; 182; 399). Simmel concludes the argument with an observation on the contemporary women's movement. He writes that

today no one can predict either direction or limitation of the movement for the emancipation of women. However, this much can be said, that already many women as individuals are aware of their position at the intersection of many circles. On the one hand, they feel closely tied to the individuals and the activities, which fill their personal life. But they are conscious, on the other hand, of their solidarity with all women (502; $183 ; 401)$.

These remarks on the emerging women's movement illustrate well Simmel's conception of 'interaction' (Wechselwirkung): the emergence of an actual concept and circle of women coincides and mutually interacts with the diminishing of their absolute difference to men, whereby he does not take a position on whether there is causality running one way or the other. When previously women had been very different, there was no concept of female difference and no interaction between actual women; they had simply existed as fixed entities within fixed circles (the family, the household) without experiencing any intersectionality. This has changed in the context of modernity: woman is a circle now that has multiple intersections. This example points to a key aspect of Simmel's sociology, an underlying, very nineteenth-century, optimistic liberal belief in generally evolving progress and modernization that manifests itself in increasingly complex individuality and the multiplication of intersecting circles.

\section{SIMMEL AND THE WOMEN'S MOVEMENT}


Simmel's account of the increased intersectionality of women in modernity in the sixth chapter of Sociology can be contextualised by several less canonical texts on the women's movement that elucidate the nearly-feminist aspects of his perspective. In spite of an isolated attempt at promoting his writings on gender issues by Lewis Coser (1977) and an edition of some of his writings On Women, Sexuality, and Love by Guy Oakes (Simmel 1984), Simmel failed to have much lasting impact on modern feminism, and for good reasons. ${ }^{14}$ Already in his own time only representatives of the bourgeois women's movement took note of and embraced Simmel's writings on women, while its more radical representatives rejected Simmel's notion that women were 'the less differentiated, less gendered [geschlechtslosere] being' that lacked a 'principle of development' (Dahme and Köhnke 1985, p. 13; Witz 2001). Simmel held, in this vein, that men are more different from each other than women are, because men are more prone to 'standing in the intersections of social circles': women lack intersectionality and therewith individuality and modernity. ${ }^{15}$

${ }^{14}$ The volume by Oakes does not contain Simmel's earlier writings on the subject in which Simmel's more conservative tendencies are less obvious (Dahme 1988, p. 425). Van Vucht Tijssen (1991) writes that Marianne Weber held against Simmel that also women want to engage with and within 'objective culture' and welcomed the fact that modernization opens up this possibility. Lichtblau discusses Simmel's use of a metaphysical notion of gender polarity for a critique of modern, masculine 'objective' culture (Lichtblau 1996, pp. 292315). Comparing Simmel to Tönnies, he writes that Tönnies sees no room for a female contribution to modern 'objective culture' and therefore exiles femininity into a utopian space that will emerge after the final (re-)mutation of Gesellschaft into Gemeinschaft will have abolished the distinction between objective and subjective culture as such, whereas Simmel who is more accepting of the reality of modern bourgeois society looks for a way how women can contribute to and improve objective culture in the present where their traditional realm - the house economy - is in the process of disappearing (ibid., 300-301). Leck presents Simmel rather enthusiastically as a key figure in German modernism and argues that he employed what looks like a conservative strategy, the maintenance of 'naturalized conceptions of gender', in pursuit of progressive social change that had egalitarian and emancipatory traits. He suggests that Simmel went far beyond what bourgeois feminists aimed for, namely a 'complete revolution in culture', anticipating 1970s/1980s 'cultural feminism' (Leck 2000, p. 142). Vromen (1987), Moser-Stark (2003) and Parkins (2009) discuss Simmel's tendency to construct femininity as 'the other' of modernity. The sixth chapter of Sociology is not referenced by any of these commentators.

${ }^{15}$ Dahme and Köhnke (1985, p. 15-16) point out that Simmel also distinguished (in some of his later writings) 'qualitative individualism' from 'modern' or 'quantitative or sociological individualism'. The latter is the individualism that emerges in 'the intersections of social circles' as described in the sixth chapter of Sociology, while the former is not socially determined. Those who are characterised by 'qualitative individuality' have 'the power to give themselves their own norms, to live only by their own ideals and their own laws.' Paradigmatic personalities of this type are Rembrandt and Goethe. This dimension of 
Simmel's position on both, the women's movement and the labour movement, can be gauged from an article he wrote on a Berlin women's conference in 1896, titled 'The Women's Conference and Social Democracy' (Simmel 1985 [1896], pp. 133-8). Simmel argues here that the positions of the bourgeois and the proletarian women's movements are 'first of all antagonistic to each other' (Simmel 1985, p. 136), but - in the sense of his concept of reciprocity - 'two sides of the same total social phenomenon (sozialen Gesamterscheinung)' (Simmel 1985, p. 138): the same industrial development has destroyed 'the natural division of labour between the sexes' for both classes, but in different ways: proletarian girls and women who have been 'thrown' into industrial production are being deprived of the protection through the family and prevented from fulfilling their domestic duties, which is why their 'social freedom' (namely the freedom to engage in wage labour) must be limited for their own good; bourgeois women, by contrast, are being deprived of sufficiently fulfilling functions in the household, so that they long to expand their 'social freedom' in the search for new fields of fulfilling activity:

The household, from which the proletarian woman is violently evicted, violently holds back the bourgeois woman; the independent economic activity that has become a curse for the former, would be a blessing for the latter (Simmel 1985, p. 137).

Simmel asserts that 'being a woman' can have entirely different meaning depending on differing class positions. Both groups' suffering is caused by the same problem: 'the development of objective social relations', the 'culture and technology of things (Kultur und Technik der Sachen)', has 'progressed faster than the development and adaptation of the individuals' (Simmel 1985, p. 137). Both movements, although pursuing apparently opposite goals, ought therefore to cooperate to correct this mismatch, that Simmel by implication imagines to be only a temporary kind of, as it were, uneven development.

This argument is framed by Simmel's disapproval of the proletarian women's movement's refusal to cooperate with what they refer to as the 'ladies' movement' (while he also criticizes the bourgeois women's movement for failing to address the question of a future constitution of society at large [Simmel 1985, 136]). Simmel suggests that Social Democracy's mistaken strategic position is rooted in its Hegelian legacy:

Simmel's later thinking, evocative of Nietzsche and Lebensphilosophie, is hard to reconcile with his proto-constructivist, sociological liberalism. 
Socialism's unitary formula can be replaced by the practical work on the details of social relations just as the shibboleth of Hegelian philosophy has been replaced by the patient work of cognizing the details of the world whose gradual addition (allmählichem Zusammenfügen) one day may resolve the riddle of the whole; induction, as it were, can replace deduction, so that the whole will emerge from the sum of the particulars (Simmel 1985, p. 135).

Simmel suggests that the 'sober' and 'evolutionary' perspective that he recommends has already taken hold of the 'wider socialist circles' and adds:

This may well be, like so often, a case of just the women following through the chosen direction to its most radical ramifications, which might have to do with the less differentiated, more uniform and more impulsive character of female emotional life (größeren Undifferenziertheit, Einheitlichkeit und Impulsivität des weiblichen Gefühlslebens) (Simmel 1985, p. 135).

Traditionally having been deprived of the benefits of multiple intersections, differentiation and complexity of positioning, women are still catching up with men, which is why proletarian women still hold on to outdated and 'speculative' Hegelian 'formulas' - in particular the notion the 'socialisation of the means of production' will solve all social problems (Simmel 1985, p. 135) - which the wider socialist movement has already replaced with a commitment to piecemeal research and reform. Simmel argues that one's being a woman shapes how one's being a proletarian translates into either practical or not so practical politics. 'Being a woman', though, implies here 'slightly lagging behind societal evolution'. Simmel's thinking stands very much in the intersection of a progressive, pro-feminist and a more conservative (in fact, right-wing liberal) line of evolutionary thinking, an ambiguity that makes reading Simmel's text all the more interesting. In the remainder of the article I will explore whether the progressive side of Simmel can be read against the more conservative side, and whether his account of the 'intersection of social circles' can add anything to contemporary debates on the complexity of social divisions. 


\section{SIMMEL AND THE CONTEMPORARY FEMINIST CONCEPT OF INTERSECTIONALITY}

In writing about Simmel's 'intersectional concept of individuality', I invoke a similarity between a key concept in Simmel's sociology and one of the key concepts in contemporary feminist theory and critical race studies, 'intersectionality'. Although 'intersection' is a central concept in the sixth chapter of Simmel's Sociology, the words 'intersectional' and 'intersectionality' do not occur there; these exact words are usually attributed to the AfroAmerican legal scholar, Kimberlé Crenshaw $(1989,1991)$. Others often credited with having co-originated the discourse on intersectionality include Patricia Hill Collins (1991, 1998), Elizabeth Spelman (1988), and, in Britain, Floya Anthias and Nira Yuval-Davis (1983, 1993). ${ }^{16}$ The intersectionality discourse emerged from feminist social movement contexts of the 1980s and 1990s, most prominently Black feminism in the USA. Not unlike the related discourses on 'standpoint theory' and 'situated knowledges', theoretical influences typically included Marxist feminism, critical theory and Mannheimian sociology of knowledge. Intersectionality starts out from accounts of the invisibility of the societal experiences of members of some specific groups of society, Black women most prominently, or inversely, the misrepresentation of some specific group's experience as that of a much more comprehensive category of people (such as Black men being seen as representing 'Blacks'). It is chiefly about keeping categories such as sex, race, class and sexuality fluid and dynamic enough to acknowledge that any one category (e.g. 'Blackness') does not have one fixed meaning for anyone who 'falls under' that category irrespective of what other categories he or she 'falls under', too, such as gender, class, age or sexuality. 'Being a woman' can mean entirely different things depending on whether one is of this or that ethnicity, race, sexuality, ability or age group. This important fact has been addressed as the 'mutual constitution' of categories of social division, as opposed to merely 'additive' accounts of multiple discrimination that imply - to use once more the example from Afro-American feminist literature - that one is a woman in addition to being Black, as if 'being a woman' and 'being Black' were mutually independent and stand-alone categories, identities or, with Simmel,

\footnotetext{
${ }^{16}$ More recent accounts are provided in Berger and Guidroz 2009; Bilge 2010; Brah and Phoenix 2004; Cho, Crenshaw, McCall 2013; Choo and Ferree 2010; Davis 2008; Knapp 2005; McCall 2005; Nash 2008 and 2011; Patil 2013; Yuval-Davis 2006, 2011 and 2012.
} 
'circles'. The salient point is, instead, to take in account how the social meaning of each category shapes or determines that of all the others.

The fact that 'intersectionality' became the predominant signifier (the 'buzzword') of a very large area of feminist theorizing that has developed since the 1970s, if not earlier, has been explained by Kathy Davis in terms of the fact 'that successful theories thrive on ambiguity and incompleteness' and 'provide a novel twist to an old problem' (Davis 2008, p. 70). There is surely some truth in this, but I would like to suggest that more specifically, the success of 'intersectionality' also benefited from its resonances with classical social theory: academically trained audiences might easily warm to the concept because 'intersectionality' transports and restates important and radical insights won in the context of anti-systemic movements (1970s and 1980s socialist and Black feminisms) ${ }^{17}$ in a terminology that is rooted in the wider social science tradition. Arguably, the reception of Simmel is so deeply entrenched in the American social science context that a concept that originates in Simmel might not anymore be recognizable as such (Levine, Carter, Gorman, 1976 a and b) and therewith becomes available for creative re-coding.

One of the ambiguities in the literature on intersectionality concerns which image exactly underlies the metaphor: sometimes the image of a road intersection is invoked, such as in Kimberlé Crenshaw's 1989 article that is commonly seen as the break-out moment of the discourse, whereas most often the image that 'intersectionality' points to is that of intersecting circles or other geometrical shapes. The 'road intersection' image occurs in the following passage:

Consider an analogy to traffic in an intersection, coming and going in all four directions. Discrimination, like traffic through an intersection, may flow in one direction, and it may flow in another. If an accident happens in an intersection, it can be caused by cars travelling from any number of directions and sometimes, from all of them. Similarly, if a Black woman is harmed because she is in the intersection, her injury could result from sex discrimination or race discrimination (Crenshaw 1989, p. 149).

${ }^{17}$ A key text was Angela Davis' Women, Race and Class (1981) that inspired many of those Black feminists who contributed to the emerging intersectionality discourse. 
Some commentators have pointed out that the image of the road intersection does actually not serve Crenshaw's argument very well as roads are not mutually constituted by their intersections (Walgenbach 2010, p. 248). Similarly, Yuval-Davis has called the image 'additive' and criticises it as simplistic (Yuval-Davis 2006, p. 196). At an actual crossroads one is run over by a car from either this or that direction, but no car ever comes from several directions at the same time. The most important aspect of the intersectionality paradigm is not transported by the road intersection image.

It is significant to note that Crenshaw often uses 'interaction' as a near-synonym of 'intersection'. She states, for example, that she 'used the concept of intersectionality to denote the various ways in which race and gender interact... I have used intersectionality as a way to articulate the interaction of racism and patriarchy generally' (Crenshaw 1991, pp. 1244 and 1265). If 'intersection' is meant to illustrate the notion of 'interaction', then the image of the road intersection is unhelpful: the image of intersecting circles much better illustrates 'interaction' - which in turn recalls Simmel's term 'Wechselwirkung' - as circles can be figured as force fields in whose intersections something happens that does not happen in neighbouring spaces. Venn-diagram-style intersection also points to more durable conditions than the image of a car crash does. In fact, many contributors to the intersectionality discourse seem to think of intersecting circles rather than of roads, as can be seen from visual materials such as book covers and conference posters. As early as 1981 images of intersecting circles were used 'to illustrate how ethnicity, class and gender contributed alone, and in interaction, as material and normative bases of domination, none of which necessarily had priority' (Denis 2008, p. 680). ${ }^{18}$ Reading intersectionality in terms of intersecting circles best reflects the actual content of the feminist and anti-racist discourse on intersectionality.

Whether the shared use of the image of 'the intersections of social circles' in Simmel and the contemporary intersectionality discourse can be attributed to a continuous if unacknowledged presence of Simmel's conception within the social science tradition is of course a speculative argument. Another argument to the same effect is perhaps more relevant: intersectionality theory is most likely to be formulated by outsiders with an insight, a notion whose original formulation by the sociology of knowledge, perhaps not incidentally, can be

\footnotetext{
${ }^{18}$ Carastathis (2008) uses drawings of intersecting circles to illustrate 'the intersectional model of identity'. The cover of Berger and Guidroz (2009) shows intersecting circles and squares.
} 
traced back to another highly influential chapter of Simmel's Sociology, the excursus on 'The stranger'. Simmel and Lazarus, from whom Simmel borrowed the image of the intersecting circles, pioneered modern social science out of the 'double consciousness' (to use Du Bois' term, another Berlin University alumnus) of German-speaking Jews in what was then the Austrian-Hungarian Empire, and out of the cognitive dissonances this situation produced. Beyond the general relevance of an overarching social theory tradition influenced by Simmel, one can hear a distant echo from those classic 'outsiders' in the discourse on 'intersectionality' as conceived by Afro-American feminists a century later, similarly outsiders in another very large, multi-ethnic state equally preoccupied with issues of integration and assimilation. Other feminists who contributed to this discourse, such as Yuval-Davis and Anthias, surely learned a thing or two about strangers and intersections in Israel and Cyprus, respectively. Patricia Hill Collins, the preeminent figure of Black feminist thought, has repeatedly embraced the sociological motives of 'the outsider' and 'the stranger' (Collins 1986, 2005). Lazarus, Simmel, Crenshaw and others described the same modern society which made them use the same image in order to express similar, albeit not identical ideas about this reality, being socially located in places where intersectionality is evident and problematic enough to provoke intersectional theories.

When looking at Simmel's account of the 'intersection of social circles' from the perspective of the contemporary discourse on intersectionality, one finds that Simmel's conception does allow him to account for the mutual constitution of several different aspects of an individual's positioning at the intersection of several social circles. Simmel describes on several occasions how the intersection changes the meaning of all intersecting circles (i.e. categories) but does not put much emphasis on this: his guiding interest in his chapter on 'intersecting circles' is with something else, namely a theory of increasingly complex individuality as the signature of modernity. Simmel formulates intersectionality theory in passing, as it were.

An example of 'strong intersectionality' in Simmel's text is the passage on military service under conditions of universal draft when a 'high placed man' must obey someone of lower status (Simmel as above, $478 ; 154 ; 381$ ). In this particular constellation, social positioning in terms of class and level of formal education has a different meaning from that it will have elsewhere. The meaning of belonging to that particular 'social circle' is constructed in the intersection with other circles, such as the circle 'military'. High social status in society at large might translate as less powerful positioning in the army, or might on 
occasion even be a disadvantage (when, say, an officer from a lower class background takes some form of class revenge on 'a toff'). Another example mentioned before is that of 'the tutor of a prince': the meaning of the social role of the 'tutor' is constructed by who the student is. Far from fixed, it is contingent on its intersectional positioning. Most striking is perhaps Simmel's discussion of how household and 'independent economic activity' have opposite social meanings for bourgeois and proletarian women respectively (Simmel 1985, p. 137): the freedom to engage in wage labour liberates bourgeois women from domestic confinement, while it evicts proletarian women from a (supposedly) protective family home. The extent to which the structure of Simmel's argument allows for complexity is here more admirable than is the dubious proposition wage labour prevented proletarian women from fulfilling their domestic duties: many women surely welcomed being rid of those 'duties', albeit others - not without reason - doubted the benefits of 'being emancipated' into the capitalist labour market.

Two further formulations from Simmel's text deserve being mentioned for how closely they anticipate images used in contemporary feminist theory: Simmel's proposition that social divisions can be 'traversed' by way of consciousness ('Durchquerung'; Simmel as above, 494; 173; 394) anticipates aspects of the feminist concept of 'transversal politics', a critique of 'identity politics' and the politics of 'empowerment' of 'communities' first proposed by Italian feminists in the 1970s. They used the concept to emphasize that women from different national backgrounds participated in their grassroots activities not 'simplistically as representatives of their groupings' (Yuval-Davis 1994, p. 192, 194). ${ }^{19}$ This notion is part of a tradition of feminist rejections of communitarianism that accept that 'identity' and 'the self' are 'situated' by belonging to a 'community' but not determined by it: the possibility of 'traversing' circles at their intersections holds out the promise of emancipation, which clearly resonates with Simmel's conception. Likewise, Simmel's image of the 'system of coordinates' (Simmel as above, $466 ; 140 ; 371)$ that is constituted by the intersecting of social circles and defines the individual reverberates in Patricia Hill-Collins' concept of the 'matrix of domination' (Collins 1991, p. 225). In the latter, the emphasis is on domination, of course, rather than constitution of the individual.

\footnotetext{
${ }^{19}$ Similar imagery can be found in Foucault who also drew on the discourses of 'new' social movements: 'Just as the network of power relations ends by forming a dense web that passes through apparatuses and institutions, without being exactly localized in them, so too the swarm of points of resistance traverses social stratifications and individual unities' (Foucault 1990, p.96).
} 


\section{INTERSECTIONAL SOCIETY'S PROGRESS}

Simmel's conception of the 'intersection of social circles' is on the one hand, highly generic - he suggests the concept can be applied to any form of human sociality as in his discussion of Australian Aborigines - on the other hand specifically relevant to modern society as he posits, in a manner reminiscent of progressivist, nineteenth-century liberal thinking (as in Spencer), a general tendency towards 'social differentiation' which to describe and illustrate is the function of Simmel's concept of intersections: all human society is intersectional, but modern society is so to a much greater extent. For Simmel, intersectionality brings complexity, complexity brings more determinate individuality, and both together are the signature of civilizational progress. ${ }^{20}$ The circles - in the double meaning of the term: more abstract categories and more concrete groups - themselves are more 'organic', or primitive in pre-modern contexts, such as those ancient category-groups of age and sex, and more dependent on intellectually articulated purposes in modernity, with the 'republic of scholars' as the circle where one can be most individual, i.e. most human (still a good idea, although increasingly precarious). Most remarkable is perhaps Simmel's distinction - not quite explicit, but clear enough - between 'women' as a simply ascriptive category, or group, before the modern period and 'women' as an actual group that forms solidarity on the basis of an intellectually articulated purpose - emancipation - in the present.

Simmel's account of the intersection of social circles, like his conception of modernity in general, does acknowledge that an increasingly complex society forces the increasingly individualized individual to face problems, namely ambivalence and lack of security (anticipating aspects of the 'risk society' of contemporary sociology [Beck 1992]). Simmel's liberal optimism prevails, though: the necessity to reconcile an increasing 'diversity of group-interests' $(468 ; 141 ; 373)$ strengthens the 'unity' or 'integrity of the personality' which is something many contemporary readers will acknowledge: the strength needed to form a strong personality let alone to oppose societal domination and exploitation comes, if it comes at all, from overcoming adversity and working through the contradictions of one's positioning. Beyond this, Simmel touches (briefly) on the question of power differentials, such as in the already mentioned cases of a 'high placed man' drafted into the army and that

\footnotetext{
${ }^{20}$ Levine (1991) emphasized the centrality of the value of individuality throughout Simmel's work.
} 
of 'the tutor of a prince'. Points Simmel makes on the intersections of nation and religion are echoed by contemporary studies (e.g. Marx 2003; Gorski 2003). Simmel does not take up the issue of 'race', a subject German sociologists at the time tended to bracket out if at all possible (Bodemann 2014) - although he briefly mentions Jewishness, which was then in the German context the prime example of 'race'. The fact that he contrasts Jewishness with Catholicism, however, indicates that Jewishness comes for him under 'religion', not 'race'. Simmel directly addresses sex and class, though.

Whereas he had referred to sex as a pre-modern, 'organic' category or group earlier in the same chapter, Simmel discusses 'women' and 'workers' in parallel as two typically modern 'circles' whose constitution involves processes of abstraction and intellectual reflection. As for workers, the argument goes that the diversity of trades that results from the increasing division of labour is 'traversed' by a growing awareness of all workers' shared opposition to capital, which becomes real only through consciousness of it. Likewise, women are forming in the modern period 'a higher circle that is defined by a general concept' ( 501 ; $182 ; 399)$ because increasing differentiation and an incipient tendency towards equality enables women to gain consciousness of their (already diminishing) difference from men. It is implied that 'woman' is a 'higher circle' now because it is based on social awareness and the formation of a concept, i.e. intellectual effort. These modern circles, 'worker' and 'woman', do not emerge spontaneously but through purposeful and reflective intervention, and are thus indicative of the increasing humanity of humanity. ${ }^{21}$ In Simmel's description, the modern, multiply intersecting and therefore self-conscious and active category 'woman', organized around a consciously formulated societal purpose, emancipation, is a modern development and results from the relative weakening, if not disappearance of what women may have been like before the modern period: fundamentally different from men but totally isolated as members of the family, unable actually to form a 'social circle' in the more concrete sense of the word. Simmel conceives of the emergence of the modern category 'woman' - both the concept and its actuality - as the result of the disintegration of the old order. This historical tendency in turn contributes to and intensifies the process of modernization.

\footnotetext{
${ }^{21}$ This conception resembles Georg Lukács's conception of proletarian 'standpoint' and the role of consciousness for the emancipation struggle (Lukács 2010) that was central for some strands of 1970s and 1980s socialist-feminist theory (e.g. Hartsock 1979). Lukács was a student of Simmel.
} 
For Simmel, increasing intersectionality means increasing individuality which in turn means increasing modernity. In this respect, Simmel's discussion of 'the intersection of social circles' is a form of historical sociology: his often so-designated 'formal sociology' is in fact a historical sociology of social forms. Although Simmel is all in all a much less confidently 'Whiggish' believer in evolutionary progress than for example Spencer may have been, the sixth chapter of Sociology is clearly underpinned by a sense that a historical tendency towards increasing complexity is inherent in the history of modern society. This sense in turn is the basis of the belief that women and other laggards in the evolution of humanity will inevitably be emancipated into a state of majority and equality by stepping into more and more intersections of social circles, i.e. taking part more fully in modern, liberal, capitalist civilization. In other texts by Simmel, this liberal perspective is counteracted by the quasiromantic, utopian belief that the potentially transcendental powers of femininity should be protected from the banal workings of 'objective culture', which means 'woman' should better not intersect with too many other 'circles' lest 'femininity' spend itself like small change does. Although either perspective would seem either naïve or objectionable nowadays when explicitly stated, implicitly both seem still operative in the discourses of emancipatory movements: the question whether emancipation of the individual comes from increased participation in the institutions and practices of modern, liberal society (wage labour, the state, the 'culture industry' etc.), or whether it depends on the protection of remaining vestiges of genuine individuality (or femininity, family values, indigenousness, spirituality, etc.) from colonization by 'the system' remains as acute as it was in Simmel's time.

The case is different with the nineteenth-century belief in the inevitability of progress that would seem quaint at least to those socialised in the period after circa 1968 when both 'Eastern' and 'Western' versions of the 'lower case liberal' paradigm of modernization theory were irreparably damaged (Wallerstein 1995). The opposite perspective, namely that progress and individuality are gradually diminishing in the process of modernization first asserted itself forcefully during World War I which progressive intellectuals like Simmel or Durkheim initially still had welcomed in the name of the defence of the 'civilization' they credited with carrying forth individualism and emancipation. This kind of defence turned out self-defeating, but it took World War 2, the Holocaust and another two eventful decades until scepticism corroded the belief in progress.

Simmel's account of the intersection of social circles and contemporary intersectionality theory fundamentally differ in that intersectionality in Simmel is seen as 
enabling, whereas feminist intersectionality theory aims to describe and explain how structural aspects of modern society limit emancipation and produce inequality and exploitation. This difference is related to the changed overall perspective on modernity. Simmel's point that increasing intersectionality is one of the 'benchmarks of civilization' (Simmel as above, $464 ; 138 ; 370$ ), however, remains as an important contribution: a formal characteristic of modern society that was visible to observers like Lazarus, Simmel and Cooley has meanwhile become ever the more a signature of modern society which is reflected in its status as a 'buzzword'. The contemporary importance of the concept in its feminist theory version confirms, in turn, the significance of the concept coined by Lazarus and Simmel.

\section{REFERENCES}

Anthias, Floya, and Nira Yuval-Davis. 1983. "Contextualising Feminism - Gender, Ethnic and Class Divisions". Feminist Review 15: 62-74.

Anthias, Floya, and Nira Yuval-Davis. 1993. Racialized Boundaries. London: Routledge.

Beck, Ulrich. 1992. Risk Society, Towards a New Modernity. London: Sage.

Belke, Ingrid. 1971. "Einleitung”. Pp. xiii-cxxxviii in her Moritz Lazarus und Heymann Steinthal, Die Begründer der Völkerpsychologie in ihren Briefen, mit einer Einleitung herausgegeben von Ingrid Belke. Tübingen: Mohr.

Benzer, Matthias. 2011. The Sociology of Theodor Adorno. Cambridge, New York: Cambridge University Press.

Berger, Michele Tracy, and Kathleen Guidroz, eds. The Intersectional Approach, Transforming the Academy through Race, Class, and Gender, Chapel Hill: The University of North Carolina Press.

Bilge, Sirma (2010). 'Recent Feminist Outlooks on Intersectionality', in Diogenes 225, 58 72.

Bodemann, Michal. 2014. "Coldly admiring the Jews: Werner Sombart and Classical German Sociology on Nationalism and Race”. Pp. 110-134 in: Stoetzler, Marcel, ed., Antisemitism and the Constitution of Sociology. Lincoln and London: University of Nebraska Press. 
Brah, Avtar, and Ann Phoenix. 2004. "Ain't I a Woman? Revisiting Intersectionality.” Journal of International Women's Studies 5(3):75-86.

Breiger, Ronald L.. 1974. “The Duality of Persons and Groups”. Social Forces 53(2):181190.

Bunzl, Matti. 2003. "Völkerpsychologie and German-Jewish Emancipation”. Pp. 47-85 in Penny, H. Glenn and Matti Bunzl, eds. Worldly Provincialism, German Anthropology in the Age of Empire. Ann Arbor: The University of Michigan Press.

Carastathis, Anna. 2008. 'The invisibility of privilege: A critique of intersectional models of identity', in: Les ateliers de l'éthique 3:2, 23-38

Cho, Sumi; Kimberlé Williams Crenshaw; Leslie McCall. 2013. 'Toward a Field of Intersectionality Studies: Theory, Applications, and Praxis'. Signs 38:4, 785-810.

Choo, Hae Yeon, and Myra Marx Ferree. 2010. "Practicing Intersectionality in Sociological Research: A Critical Analysis of Inclusions, Interactions, and Institutions in the Study of Inequalities". Sociological Theory 28(2):129-149.

Collins, Patricia Hill. 1986. 'Learning from the Outsider Within: The Sociological Significance of Black Feminist Thought', in: Social Problems 33:6, pages 14-32.

Collins, Patricia Hill. 1991._Black Feminist Thought. Knowledge, Consciousness and the Politics of Empowerment. New York: Routledge.

Collins, Patricia Hill. 1998. "It's all in the family: Intersections of gender, race, and nation". Hypatia 13(3):62-82.

Collins, Patricia Hill. 2005. 'That's Not Why I Went to School', in: Alan Sica, Stephen Turner, eds., The Disobedient Generation, Social Theorists in the Sixties, Chicago: University of Chicago Press, 94-113.

Cooley, Charles Horton. (1902) 1922. Human Nature and the Social Order (Revised Edition). New York: Charles Scribner's Sons.

Coser, Lewis A. 1977. “Georg Simmel's Neglected Contributions to the Sociology of Women”. Signs. Journal of Women in Culture and Society 2:869-876.

Coser, Lewis A. 2003. Masters of Sociological Thought. Ideas in Historical and Social Context. Second Edition. Long Grove, Ill.: Waveland.

Crenshaw, Kimberlé. 1989. "Demarginalizing the Intersection of Race and Sex: A Black Feminist Critique of Antidiscrimination Doctrine, Feminist Theory and Antiracist 
Politics". The University of Chicago Legal Forum Volume 1989, Feminism in the Law: Theory, Practice and Criticism: 139-167.

Crenshaw, Kimberlé. 1991. "Mapping the Margins: Intersectionality, Identity Politics, and Violence against Women of Color". Stanford Law Review 43(6):1241-1299.

Dahme, Heinz-Jürgen, and Klaus Christian Köhnke. 1985. “Einleitung”. Pp. 7-26 in Simmel, Georg. Schriften zur Philosophie und Soziologie der Geschlechter, herausgegeben und eingeleitet von Heinz-Jürgen Dahme und Klaus Christian Köhnke. Frankfurt/M:

Suhrkamp.

Dahme, Heinz-Jürgen. 1988. “On Georg Simmel's Sociology of the Sexes”. Politics, Culture, and Society 1(3):412-430.

Davis, Angela. 1981. Women, Race and Class. New York: Random House.

Davis, Kathy. 2008. "Intersectionality as buzzword, A sociology of science perspective on what makes a feminist theory successful”. Feminist Theory 9(1):67-85.

Denis, Ann. (2008). 'Intersectional Analysis: A Contribution of Feminism to Sociology', International Sociology 23(5), 677 -694.

Diani, Mario. 2000. "Simmel to Rokkan and Beyond: Towards a Network Theory of (New) Social Movements". European Journal of Social Theory 3(4):387-406.

Erikson, Emily. 2011. "Formalist and Relationalist Theory in Social Network Analysis". [draft downloaded from:

https://www.pop.upenn.edu/sites/www.pop.upenn.edu/files/Formalism\%20and\%20Relati onalism\%20in\%20Social\%20Network\%20Theory4-1.pdf (accessed 11. 9. 2012)].

Foucault, Michel. 1990. The History of Sexuality, Vol. I: An Introduction, The will to knowledge, London: Penguin

Frisby, David. 1992. “The study of society”. In Frisby, David, ed., Simmel and Since, Essays on Georg Simmel's Social Theory. London and New York: Routledge. Pp. 5-19.

Gorski, Philip S. 2003. The Disciplinary Revolution: Calvinism, Confessionalism and the Growth of State Power in Early Modern Europe. Chicago: University of Chicago Press.

Hartsock, Nancy. 1979. "Feminist Theory and the Development of Revolutionary Strategy". Pp. 56-77 in Eisenstein, Zillah R., ed. Capitalist Patriarchy and the Case for Socialist Feminism. New York and London: Monthly Review Press. 
Jacobs, Glenn. 2006. Charles Horton Cooley, Imagining Social Reality. Amherst and Boston: University of Massachusetts Press.

Kalmar, Ivan. 1987. "The Völkerpsychologie of Lazarus and Steinthal and the Modern Concept of Culture". Journal of the History of Ideas 48(4):671-690.

Knapp, Gudrun-Axeli. 2005. "Race, Class, Gender. Reclaiming Baggage in Fast Travelling Theories". European Journal of Women's Studies 12(3):249-265.

Lazarus, Moritz. (1862) 2003. "Ueber das Verhältniß des Einzelnen zur Gesammtheit”. Pp. 39-129 in: Grundzüge der Völkerpsychologie und Kulturwissenschaft, Herausgegeben, mit einer Einleitung und Anmerkungen versehen von Klaus Christian Köhnke. Hamburg: Meiner.

Lazarus, Moritz. (1879) 2008. "What does National mean?” Appendix to: Stoetzler, Marcel. The State, the Nation and the Jews, Liberalism and the Antisemitism Dispute in Bismarck’s Germany. Lincoln and London: University of Nebraska Press, pp. 317-59.

Leck, Ralph Matthew. 2000. Georg Simmel and avant-garde sociology: the birth of modernity, 1880-1920. Amherst, NY: Humanity Books.

Levine, Donald N. 1991. "Simmel as Educator: On Individuality and Modern Culture". Theory, Culture \& Society 8, pp. 99-117.

Levine, Donald N., Ellwood B. Carter, Eleanor Miller Gorman. 1976 a. "Simmel's Influence on American Sociology I". American Journal of Sociology 81(4):813-845.

Levine, Donald N.; Ellwood B. Carter, Eleanor Miller Gorman. 1976 b. "Simmel's Influence on American Sociology II”. American Journal of Sociology 81(5):1112-1132.

Lichtblau, Klaus. 1996. Kulturkrise und Soziologie um die Jahrhundertwende. Zur Genealogie der Kultursoziologie in Deutschland. Frankfurt/Main: Suhrkamp.

Lukács, Georg (2010). History and Class Consciousness. Studies in Marxist Dialectics. Pontypool: The Merlin Press

Marx, Anthony. 2003. Faith in Nation. Exclusionary Origins of Nationalism. Oxford: Oxford University Press.

McCall, Leslie. 2005. "The complexity of intersectionality”. Signs: Journal of Women in Culture and Society 30(3):1771-1800. 
Moser-Stark, Denise. 2003. "Georg Simmels Kultursoziologie der Geschlechter" [http://socio.ch/sim/on_simmel/t_moser.htm (accessed 25.4. 2013)].

Nash, Jennifer C. 2008. “Re-thinking Intersectionality”. Feminist Review 89(1):1-15.

Nash, Jennifer C., 2011, „,Home Truths“ on Intersectionality“, Yale Journal of Law and Feminism 23:2, 445-470.

Nollert, Michael. 2010. "Kreuzung sozialer Kreise: Auswirkungen und Wirkungsgeschichte". in Stegbauer, Christian und Rainer Häussling, eds. Handbuch Netzwerkforschung. Wiesbaden: VS Verlag für Sozialwissenschaften, pp. 159-167.

Parkins, Ilya. 2009. "Fashion, Femininity, and the Ambiguities of the Modern: A Feminist Theoretical Approach to Simmel”, in: Kim, David D., ed., Georg Simmel in Translation: Interdisciplinary Border Crossings in Culture and Modernity. Newcastle upon Tyne: Cambridge Scholars Publishing. Pp. 28-49.

Patil, Vrushali. 2013. "From Patriarchy to Intersectionality: A Transnational Feminist Assessment of How Far We've Really Come”. Signs 38:4, pages 847-867.

Pescosolido, Bernice A.; Beth A. Rubin. 2000. "The web of group affiliations revisited: social life, postmodernism, and sociology" American Sociological Review 65:52-76.

Petzke, Martin. 2011. „Soziale Differenzierung im Werk Georg Simmels - mit besonderem Blick auf Wilhelm Dilthey“. In: Tyrell, Hartmann; Otthein Rammstedt; Ingo Meyer, eds., Georg Simmels große ,Soziologie‘. Bielefeld: transcript, pp. 149-180.

Rieff, Philip. 1993. "Introduction”. In: Cooley, Charles Horton. Social Organization, A Study of the Larger Mind. New Brunswick: Transaction Publishers, pp. xv - xxx.

Rock, Paul. 1979. The making of symbolic interactionism. London: Macmillan.

Schmid, Hans Bernhard. 2005. "'Volksgeist'. Individuum und Kollektiv bei Moritz Lazarus (1824-1903)". Dialektik, Zeitschrift für Kulturphilosophie 16(1):157-170.

Schober, Anna. 2009. „Von Kreuzungen zu Knotenpunkten und zwiespältigen Artikulationen. Das Denken der Kontingenz von Gemeinschaften im Wandel“. In: Rol, Cécile; Christian Papilloud, eds., Soziologie als Möglichkeit. 100 Jahre Georg Simmels Untersuchungen über die Formen der Vergesellschaftung. Wiesbaden: VS Verlag für Sozialwissenschaften, pp. 135-161. 
Simmel, Georg. (1896) 1985. "Der Frauenkongreß und die Sozialdemokratie”. Pp. 133-138 in Simmel, Georg. Schriften zur Philosophie und Soziologie der Geschlechter, herausgegeben von Heinz-Jürgen Dahme und Klaus Christian Köhnke. Frankfurt/Main: Suhrkamp.

Simmel, Georg. (1908) 1992. Soziologie. Untersuchungen über die Formen der Vergesellschaftung, herausgegeben von Otthein Rammstedt, Gesamtausgabe Band 11. Frankfurt/M: Suhrkamp.

Simmel, Georg. 1950. The Sociology of Georg Simmel. Translated, edited and with an introduction by Kurt H. Wolff. Glencoe, Ill.: The Free Press.

Simmel, Georg. 1955. "The Web of Group Affiliations (translated by Reinhard Bendix)" in Conflict, translated by Kurt H. Wolff/ The Web of Group-Affiliations, translated by Reinhard Bendix. Edited by Kurt H. Wolff. New York: The Free Press, pp. 125-195.

Simmel, Georg. 1984. On Women, Sexuality, and Love. Translated and with an introduction by Guy Oakes. New Haven/ London: Yale University Press.

Simmel, Georg. 1989. Aufsätze 1887 bis 1890. Über sociale Differenzierung (1890). Die Probleme der Geschichtsphilosophie (1892), Gesamtausgabe Band 2, Herausgegeben von Heinz-Jürgen Dahme. Frankfurt/Main: Suhrkamp.

Simmel, Georg. 2009. Sociology: Inquiries into the Construction of Social Forms (2 vols.), Translated and edited by Anthony J. Blasi, Anton K. Jacobs and Mathew Kanjirathinkal, with an introduction by Horst J. Helle. Leiden: Brill.

Spelman, Elizabeth. 1988. Inessential Woman. Boston: Beacon Press.

Stoetzler, Marcel. 2008 a. The State, the Nation and the Jews, Liberalism and the Antisemitism Dispute in Bismarck's Germany. Lincoln and London: University of Nebraska Press.

Stoetzler, Marcel. 2008 b. "Cultural difference in the national state: from trouser-selling Jews to unbridled multiculturalism". Patterns of Prejudice 42(3):245-279.

Stoetzler, Marcel. 2010. "Antisemitism, capitalism, and the formation of sociological theory". Patterns of Prejudice 44(2):160-193.

Stoetzler, Marcel. 2014. 'Moritz Lazarus und die liberale Kritik an Heinrich von Treitschkes liberalem Antisemitismus', in: Hans-Joachim Hahn and Olaf Kistenmacher, eds., 
Beschreibungsversuche der Judenfeindschaft, Berlin and Boston: de Gruyter (Europäisch-Jüdische Studien), pp. 98-120.

Van Vucht Tijssen, Lieteke. 1991. "Women and Objective Culture: Georg Simmel and Marianne Weber". Theory, Culture \& Society 8:203-218.

Vromen, Suzanne. 1987. "Georg Simmel and the cultural dilemma of women”. History of European Ideas 8(4/5):563-579.

Walby, Sylvia. 2007. "Complexity Theory, Systems Theory, and Multiple Intersecting Social Inequalities". Philosophy of the Social Sciences 37(4):449-470.

Walgenbach, Katharina. 2010. ,Postscriptum: Intersektionalität - Offenheit, interne Kontroversen und Komplexität als Ressourcen eines gemeinsamen Orientierungsrahmens'. In: Lutz, Helma, Maria Teresa Herrera Vivar and Linda Supik, eds. Fokus Intersektionalität, Bewegungen und Verortungen eines vielschichtigen Konzeptes. Wiesbaden: VS Verlag, pp. 245-256.

Wallerstein, Immanuel. 1995. After Liberalism. New York: The New Press.

Witz, Anne. 2001. "Georg Simmel and the Masculinity of Modernity”. Journal of Classical Sociology 1(3):353-370.

Yuval-Davis, Nira. 1994. "Women. Ethnicity and Empowerment”. Feminism \& Psychology 4(1), pp. 179-197.

Yuval-Davis, Nira. 2006. "Intersectionality and Feminist Politics". European Journal of Women's Studies 13(3), pp. 193-209.

Yuval-Davis, Nira. 2011. The politics of Belonging: Intersectional Contestations. London: Sage

Yuval-Davis, Nira. 2012. 'Dialogical Epistemology - An Intersectional Resistance to the “Oppression Olympics"”, in Gender \& Society, 26:1, pages 46-54. 